\title{
Association between Neutrophil-Lymphocyte Count Ratio and Matrix Metalloproteinase-9 in Patients with Acute Myocard Infarction
}

\author{
Badai Bhatara Tiksnadi, Mohammad Rizki Akbar, A. Fauzi Yahya, Syarief Hidayat, Augustine \\ Purnomowati, Toni Mustahsani Aprami \\ Department of Cardiology and Vascular Medicine Faculty of Medicine Universitas Padjadjaran \\ Dr. Hasan Sadikin General Hospital Bandung, Indonesia
}

\begin{abstract}
The correlation between metalloproteinase-9 (MMP-9) level and neutrophil-lymphocyte count ratio (NLCR) in AMI patients has not been studied despite the fact that they are both known to predict ventricular remodeling. This study aimed to evaluate the correlation between the MMP-9 level and NLCR in patients with acute myocardial infarction. A cross-sectional study was conducted by recruiting acute coronary syndrome patients (onset within 24 hours) who were admitted to the emergency department in several hospitals around Bandung during OctoberDecember 2012. The relationship between the MMP-9 level and NLCR was analyzed using Pearson correlation test. Linear regression analysis was used to measure the strength of NLCR in MMP-9 level prediction. Thirty seven patients aged $55.8+11$ years old were included in this study with mostly male patients (78\%). Seventy-six percents of the sample were ST-elevation myocardial infarct (STEMI) patients with the onset of symptoms of 6 (3-14) hours. The mean lymphocyte-neutrophil ratio was $5.24(1 \sigma \pm 2.4)$ and the MMP-9 plasma concentration was 370 (240-530) ng/mL. One-sided Pearson correlation showed a positive correlation between the two variables $(\mathrm{r}=0.44, \mathrm{p}=0.003)$. The linear regression analysis conceived the formula of MMP-9=40.87 (NLCR) + 211.3 which was used to show the relationship between the MMP-9 level and lymphocyte-neutrophil ratio. There was a positive moderate correlation between the MMP-9 level and NLCR in patients with AMI. Linear regression analysis shows that NLCR is the only independent variable to predict the MMP-9 plasma level.
\end{abstract}

Key words: Acute myocardial infarct, Matrix metalloproteinase (MMP)-9, Neutrophyl-Lymphocyte Count Ratio(NLCR), left ventricular remodeling

\section{Korelasi Rasio Neutrofil-Limfosit (NLCR) dengan Kadar Matriks Metaloproteinase-9 pada Penderita Infark Miokardium Akut}

\begin{abstract}
Abstrak
Korelasi antara matriks metaloproteinase-9 (MMP-9) dan rasio netrofil-limfosit masih belum pernah dipelajari, meskipun kedua variabel tersebut diketahui dapat memprediksi remodeling ventrikel kiri. Studi ini bertujuan mengevaluasi korelasi antara kadar MMP-9 dan rasio netrofil-limfosit pada penderita infark miokardium akut. Penelitian dilakukan secara potong lintang dengan sampel darah pasien dengan diagnosis kerja infark miokard akut (IMA) (onset nyeri dada <24 jam) yang diambil dari beberapa rumah sakit di sekitar kota Bandung dari periode Bulan Oktober-Desember 2012. Hubungan antara kadar MMP-9 dan rasio netrofil leukosit dianalisis dengan Uji Korelasi Pearson. Analisis regresi linier digunakan untuk mengukur kekuatan pengaruh konsentrasi rasio neutrofil-limfosit pada kadar MMP-9. Sebanyak 37 pasien berusia 55,8 \pm 11 tahun, dan 78\% di antaranya adalah pria menjadi subjek dalam penelitian ini. Tujuh puluh enam persen sampel di antaranya merupakan pasien infark miokardium dengan elevasi ST dengan onset gejala $6(3-4)$ jam. Rerata rasio limfosit-neutrofil adalah 5,24 $(1 \sigma$ $\pm 2,4$ ), dan kadar konsentrasi MMP-9 sebesar 370 (240-530) ng/mL. Uji korelasi Pearson menunjukkan hubungan positif antara kedua variabel tersebut dengan nilai $r=0,44(p=0,003)$. Dari analisis regresi linier didapatkan rumus MMP-9 = 40,87 (NLCR) + 211,3, yang digunakan untuk menunjukkan hubungan antara kadar MMP-9 dan rasio limfosit-netrofil. Terdapat hubungan positif antara kadar MMP-9 dan rasio neutrofil-limfosit pada pasien penderita IMA. Analisis regresi linier menunjukkan bahwa hanya rasio neutrofil-limfosit yang menjadi variabel prediktor independen kadar MMP-9.
\end{abstract}

Kata kunci: Infark miokardium akut, matriks metalloproteinase 9 (MMP-9), rasio limfosit-neutrofil,remodeling ventrikel kiri

Corresponding Author: Badai Bhatara Tiksnadi, Department of Cardiology and Vascular Faculty of Medicine Universitas Padjadjaran/Dr. Hasan Sadikin General Hospital Bandung, Jalan Pasteur No. 38 Bandung 40161 West Java, Indonesia, Email: tiksnadi_badai@yahoo.com 


\section{Introduction}

Ischemic heart disease remains a major threat in both developed and developing countries. Each patient is unique in the way an acute myocardial ischemic attack affects their subsequent cardiac health. Patient might experience various levels of ventricular dilation or hypertrophy severity, worsen heart failure, or possibility of a fatal arrhythmia after the index event. Left ventricular remodeling after a heart attack is a significant factor in the probability of a recurrent ischemic attack and progression of heart failure. ${ }^{1}$ Specific parameters that are able to predict the incidence of ventricular remodeling will provide valuable insight towards patient prognosis.

Matrix metalloproteinase (MMP) 9, which is one of extracellular matrix degrading proteases, plays a role in the myocardial remodeling process after an acute myocardial infarction (AMI). MMP9 belongs to a gelatinase group that degrades the fibrillar collagen component of the myocardial extracellular matrix in the basement membrane, facilitating the remodeling process. ${ }^{2,3}$ Levels of MMP-9 directly after an AMI can consistently predict the incidence of left ventricular remodeling and is also an independent predictor in future recurring cardiovascular events. ${ }^{4-6}$

MMP-9 is produced as an inflammatory response after an AMI. Other inflammatory parameters, such as white blood cell count, are cheaper to examine but neither as sensitive nor specific towards AMI when compared to MMP-9. Neutrophyl-lymphocyte count ratio (NLCR) is a new parameter routinely examined in AMI patients at admission. Any existing neutrophilia and relative lymphocytopenia present after an AMI has better diagnostic values than other parameters such as absolute leucocyte or neutrophil counts. ${ }^{7-9}$ Neutrophilia and lymphocytopenia represent more extensive process of inflammation which correlate with the size of the infarction and microvascular dysfunction; all of which contribute to the process of ventricular remodeling. ${ }^{10,11}$ NLCR also has prognostic values on post-AMI cardiovascular events. ${ }^{8,9,12}$

To the researchers' knowledge, no study has been performed on the correlation between levels of MMP-9 and NLCR in AMI patients even though they are both known to predict ventricular remodeling. Both parameters are proinflammatory markers and studies have shown that neutrophils induce MMP-9 activation ${ }^{13}$ while T-regulatory cells have been shown to decrease MMP-9 levels. ${ }^{14}$ The aim of this study is to investigate the correlation between NLCR and MMP-9 levels of in post-AMI patients and to help in predicting high-risk patients for leftventricular remodeling in the future.

\section{Methods}

This cross-sectional study was conducted between October to December 2012 using data collected from 3 hospitals in Bandung area, Indonesia: Dr. Hasan Sadikin General Hospital, Dustira Army Hospital, and dr. M. Salamun Air Force Hospital. Subjects were patients who were presented at the emergency department with a chief complaint of typical chest pain onset within 24 hours before admission. Patients with negative cardiac necrosis markers, acute infection, chronic lung disease, pneumonia, sepsis, malignancy, steroid/anti-inflammatory consumption, rheumatoid arthritis, systemic lupus eritomatosus, chronic kidney disease, chronic heart disease, acute stroke, acute aortic dissection, and, history of trauma and burns were excluded from this study.

Samples were selected consecutively. Due to the novelty of this study, sample size was calculated using the starting point formula in analyzing correlations with an iteration to previous, similar studies. ${ }^{15}$ The sample size for this study was determined to be 37 subjects.

Informed consent was obtained from all patients included in the study. Ethical clearance for this study was issued by the board of ethics and medical research in Dr. Hasan Sadikin General Hospital under the reference number LB.04.01/A05/EC/108/XI/2012

An additional five milliliters of peripheral blood samples were drawn together with the blood for routine blood examinations while the subjects were in the emergency department. Blood for routine blood examinations were collected using an ethylene diamine tetraacetic acid (EDTA) tube and leucocyte analysis was conducted using the Hematologic Analyzer MINDRAY BC-5300. Additional peripheral blood samples for MMP-9 analysis were stored in plain tubes and were centrifuged at the central laboratory within 24 hours. The serum was then stored in a freezer. All collected serum samples were then examined for MMP-9 using a standard ELISA method with reagent Quantikine Human MMP-9 Total Immunoassay by R\&D Systems. Cardiac necrosis marker examination was repeated when the first result was negative, with a 4-6 hour interval from the time of the first 
Table 1 Baseline Characteristics

\begin{tabular}{lcc}
\hline \multicolumn{1}{c}{ Variable } & $\begin{array}{c}\text { Mean } \pm \text { SD } \\
\text { Median }\left(\mathbf{Q}_{\text {I-III }}\right)\end{array}$ & $\begin{array}{c}\mathbf{n} \\
\mathbf{( \% )}\end{array}$ \\
\hline Age (years) & $55.8 \pm 11$ & \\
Onset (hour) & $6(3-14)$ & \\
Sex: & & \\
Man & $29(78)$ \\
Woman & $8(22)$ \\
Risk factor: & \\
Diabetes mellitus & & $15(40)$ \\
Hypertension & $23(62)$ \\
Smoking & $26(70)$ \\
Dyslipidemia & $29(78)$ \\
Family history & $3(8)$ \\
Previous medication: & \\
ACE Inhibitors & $13(35)$ \\
HMG-CoA & $9(24)$ \\
inhibitors & \\
(Statin) & \\
Diagnosis: & \\
STEMI & \\
NSTEMI & \\
\hline
\end{tabular}

collection.

Sample data were then tabulated and processed using the SPSS 16.0 software. A descriptive analysis of the data was conducted initially to delineate any pre-existing conditions within the sample size. The relationship strength between MMP-9 and NLCR plasma levels was tested through determination of Pearson's correlation coefficient. A linear regression analysis was performed between the two variables to help predicting MMP-9 plasma level using the NLCR in AMI patients.

\section{Results}

A total of 59 subjects were recruited in this study and 22 of them were excluded from the study in accordance with the exclusion criteria. A total of 37 samples were used in the final analysis. Demographic and clinical characteristics of the subjects are presented in Table 1. Statistical analysis was conducted to evaluate the correlation between MMP-9 concentration and NLCR using one-sided Pearson's correlation with a confidence interval of 95\%. There was a moderate positive correlation $(\mathrm{r}=0.44 ; \mathrm{p}<0.01)$ between MMP-9 level and NLCR as illustrated in Figure 1. Table 2 presents the peripheral

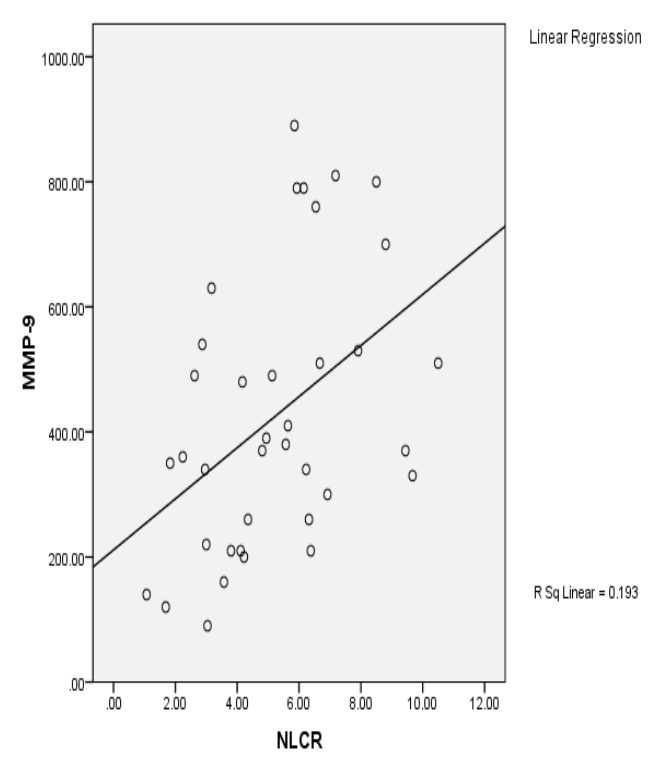

Figure 1 Scatter Diagram of NLCR and MMP-9. (Pearson's product-momencorrelation coefficient $=0.440 ; p=0.003$ )

Table 2 White Blood Cell Differentiation Counts and MMP-9 Concentrations

\begin{tabular}{lccccccc}
\hline \multicolumn{1}{c}{ Variable } & Mean & SD & Median & Min & QI & QIII & Max \\
\hline Leukocyte count & 12,027 & 3,662 & 12,540 & 5,300 & 9,350 & 14,800 & 18,600 \\
Neutrophil count & 9,298 & 3,387 & 8,960 & 3,266 & 6,871 & 11,981 & 15,810 \\
Lymphocyte count & 1,958 & 718 & 1,818 & 901 & 1,386 & 2,512 & 3,335 \\
Neutrophil (\%) & 75.76 & 9.6 & 77 & 46 & 71.5 & 83 & 88 \\
Lymphocyte (\%) & 17.84 & 7.6 & 16 & 8 & 12.5 & 23 & 43 \\
NLCR & 5.24 & 2.4 & 5.13 & 1.07 & 3.1 & 6.6 & 10.5 \\
MMP-9Level (ng/mL) & 425 & 220 & 370 & 90 & 240 & 530 & 890 \\
\hline
\end{tabular}


Table 3 Correlations of MMP-9 with NLCR and other White Blood Cell Variables

\begin{tabular}{lcc}
\hline \multicolumn{1}{c}{ Variable } & Correlation (r) & p \\
\hline Leukocyte count $\left(\right.$ per $\left.\mathrm{mm}^{3}\right)$ & 0.371 & 0.012 \\
Neutrophyl count $\left(\right.$ per $\left.\mathrm{mm}^{3}\right)$ & 0.414 & 0.005 \\
Lymphocyte count $\left(\right.$ per $\left.\mathrm{mm}^{3}\right)$ & -0.105 & 0.268 \\
NLCR & 0.440 & 0.003 \\
\hline
\end{tabular}

blood examinations results of the subjects upon admission and the concentrations of MMP-9. The characteristics of blood samples reflected absolute neutrophilia and lymphocytopenia in AMI patients. In comparison with absolute leucocyte, neutrophil, and lymphocyte values, the NLCR presented the strongest correlation with MMP-9 as shown in Table 3. Linear regression analysis was conducted between MMP-9 concentration and NLCR. Variable analyses that included infarct type, ACE-inhibitor usage, and statin usage, showed that NLCR was the only independent variable to predict MMP-9. A model-fitting formula of MMP-9 $=40.87$ (NLCR) +211.3 was conceived. According to the model summary, the equation was able to explain $17 \%$ of plasma MMP-9 level using NLCR as an independent predictor.

\section{Discussion}

The level of MMP-9 in this study subjects was similar to those in Eckart et al. ${ }^{16}$ and Fukuda et al. ${ }^{17}$ studies. Previous studies have also observed serum neutrophilia and lymphocytopenia in AMI patient samples. ${ }^{7}$ The mean of NLCR was similar to the results of Zazula et al. ${ }^{7}$;however, this present study does not differentiate NLCR between STEMI and NSTEMI.

A correlation with $\mathrm{r}=0.44$ between plasma MMP-9 and NLCR is classified as moderate strength. NLCR has the strongest correlation with MMP-9 when compared to other white blood cell variables. NLCR is known to be a better diagnostic tool and predictor of remodeling in AMI than lymphocytopenia and neutrophilia alone; hence, this study strengthens the theory that MMP-9 is a more specific diagnostic tool for AMI.

However, our model-fitting formula from the regression can only predict a small percentage (17\%) of plasma MMP-9 concentrations by using NLCR as a single independent predictor. The formula to predict another $83 \%$ of plasma MMP9 concentration can be achieved by calculating othervariables not taken into accountin this study. Some of those other variables are inflammatory parameters that are simultaneously activated in the same pathway, such as macrophage activity, TNF- $\alpha$, fibrinogen, hs-CRPor soluble CD40Ligand (sCD40L). ${ }^{18,19}$ Other sources of MMP-9 other than the neutrophils, such as fibroblasts, are also not accounted for in this study. ${ }^{20}$

There are several limitations in this study. Firstly, other inflammatory parameters which could influence MMP-9 level were not evaluated. Secondly, MMP-9 and NLCR were not examined periodically, so the temporal effect in this association cannot be analyzed. Thirdly, the crosssectional design in this study lead to difficulty in explaining direct association between NLCR and remodeling in patients with acute myocardial infarction. Further studies need to be performed with a cohort design and should include other variables that could influence remodeling such as echocardiography parameters, infarct location, or other laboratory parameters such as NT-pro BNP or MMP-2.

There is a moderate positive correlation between MMP-9 and NLCR levels in patients diagnosed with AMI. NLCR is the only independent variable to predict the MMP-9 plasma level. The concentration of plasma MMP9 could be predicted using the NLCR ratio by using the formula of MMP-9 $=40.87$ (NLCR) + 211.3.

\section{References}

1. Mann DL, Zipes DP, Libby P, Bonow RO, Braunwald E. Braunwald's heart disease: a textbook of cardiovascular medicine. In: Elsevier Saunders. 2015.

2. Yabluchanskiy A, Ma Y, Iyer RP, Hall ME, Lindsey ML. Matrix metalloproteinase-9: Many shades of function in cardiovascular disease. Physiology (Bethesda). 2013;28(6): 391-403.

3. Bonnans C, Chou J, Werb Z. Remodelling the extracellular matrix in development and 
disease. Nat Rev Mol Cell Biol. 2014;15(12): 786-801.

4. Galli A,Lombardi F. Postinfarctleftventricular remodelling: a prevailing cause of heart failure. cardiology research and practice. Cardiol Res Pract. 2016;2016:2579832.

5. Fertin M, Lemesle G, Turkieh A, Beseme O, Chwastyniak M, Amouyel P, et al. Serum MMP-8: a novel indicator of left ventricular remodeling and cardiac outcome in patients after acute myocardial infarction. PLoS One. 2013;8(8):e71280.

6. Fertin M, Dubois E, Belliard A, Amouyel P, Pinet F, Bauters C. Usefulness of circulating biomarkers for the prediction of left ventricular remodeling after myocardial infarction. Am J Cardiol. 2012;110(2):27783.

7. Zazula AD, Précoma-Neto D, Gomes AM, Kruklis H, Barbieri GF, Forte RY, et al. An assessment of neutrophils/lymphocytes ratio in patients suspected of acute coronary syndrome. Arquivos Brasileiros de Cardiologia. scielo; 2008;90(1):31-6.

8. Meissner J, Irfan A, Twerenbold R, Mueller S, Reiter M, Haaf P, et al. Use of neutrophil count in early diagnosis and risk stratification of AMI. Am J Med. 2011;124(6):534-42.

9. Muhmmed Suliman MAR, Bahnacy Juma AA, Ali Almadhani AA, Pathare AV, Alkindi SSA, Uwe Werner F. Predictive value of neutrophil to lymphocyte ratio in outcomes of patients with acute coronary syndrome. Arch Med Res. 2010;41(8):618-22.

10. Matsumoto K, Ogawa M, Suzuki J, Hirata Y, Nagai R, Isobe M. Regulatory T lymphocytes attenuate myocardial infarction-induced ventricular remodeling in mice. Int Heart J. 2011;52(6):382-7.

11. Tahto E,Jadric R,Pojskic L, Kicic E. Neutrophilto-lymphocyte ratio and its relation with markers of inflammation and myocardial necrosis in patients with acute coronary syndrome. Med Arch. 2017;71(5):312-5.

12. Azab B, Bhatt VR, Phookan J, Murukutla
S, Kohn N, Terjanian T, et al. Usefulness of the neutrophil-to-lymphocyte ratio in predicting short- and long-term mortality in breast cancer patients. Ann Surg Oncol. 2012;19(1):217-24.

13. Jönsson $S$, Lundberg $A$, Kälvegren $H$, Bergström I, Szymanowski A, Jonasson L. Increased levels of leukocyte-derived MMP9 in patients with stable angina pectoris. PLoS One. 2011;6(4):e19340.

14. Tang T-T, Yuan J,ZhuZ-F,Zhang W-C, Xiao H,Xia $\mathrm{N}$, et al. Regulatory T cells ameliorate cardiac remodeling after myocardial infarction. Basic Res Cardiol. 2012;107(1):232.

15. Rahmat B, Dinarti LK, Irmalita, Setianto BY. Perbedaan Rasio Kadar Serum MMP-9/ TIMP-1 pada kejadian infark miokard akut elevasi segmen ST (IMA-EST) dan sindroma koroner akut non elevasi segmen-ST (SKANEST. J Kardiol Indones. 2013;34:160-6.

16. Eckart RE, Uyehara CFT, Shry EA, Furgerson JL, Krasuski RA. Matrix metalloproteinases in patients with myocardial infarction and percutaneous revascularization. J Interv Cardiol. 2004;17(1):27-31.

17. Fukuda D, Shimada K, Tanaka A, Kusuyama T, Yamashita H, Ehara S, et al. Comparison of levels of serum matrix metalloproteinase- 9 in patients with acute myocardial infarction versus unstable angina pectoris versus stable angina pectoris. Am J Cardiol. 2006; 97(2):175-80.

18. Zakynthinos E, Pappa N. Inflammatory biomarkers in coronary artery disease. J Cardiol. 2009;53(3):317-33.

19. Tan J, Hua Q, Gao J, Fan ZX.Clinical implications of elevated serum interleukin-6, soluble CD40 ligand, metalloproteinase- 9 , and tissue inhibitor of metalloproteinase- 1 in patients with acute ST-segment elevation myocardial infarction. Clin Cardiol. 2008;31(9):413-8.

20. Jyer RP, Jung M, Lindsey ML. MMP-9 signaling in the left ventricle following myocardial infarction. Am J Physiol-Hear Circ Physiol. 2016;311(1):H190-8. 